\title{
Homogeneous Regions for Rainfall Distribution in the City of Rio De Janeiro Associated to the Risk of Natural Disasters
}

\section{Renato Marques Sanches Pereira}

UFRRJ: Universidade Federal Rural do Rio de Janeiro

Henderson Silva Wanderley

UFRRJ: Universidade Federal Rural do Rio de Janeiro

Rafael Coll Delgado ( $\square$ rafaelcolldelgado32@gmail.com )

Universidade Federal Rural do Rio de Janeiro: Universidade Federal Rural do Rio de Janeiro https://orcid.org/0000-0002-3157-2277

\section{Research Article}

Keywords: Natural disasters, rainfall, floods, mass movements, homogeneous groups.

Posted Date: June 11th, 2021

DOI: https://doi.org/10.21203/rs.3.rs-592809/v1

License: (c) (i) This work is licensed under a Creative Commons Attribution 4.0 International License. Read Full License 


\section{Abstract}

Understanding the occurrence of natural disasters in regions where the occurrence is high is very important, it is known that the occurrence of disasters associated with intense rains are a source of research in different locations around the globe, being important not only for increasing accuracy of weather forecasting models, but important information for civil defense, where lives can be saved. The increase in the occurrence of natural disasters related to extreme rainfalls has become a problem of large urban centers, such as the city of Rio de Janeiro (CRJ). Thus, the identification of homogeneous regions for rainfall distribution (HRRD) becomes essential to identify regions at risks of floods and mass movements. The aim of this research was to identify HRRD in CRJ associated to the risk of natural disasters. The identification of homogeneous regions was carried out with the use of monthly rainfall data from 14 pluviometric stations spatially distributed in the study area between 1997 and 2018. Rainfall data were submitted to descriptive statistical analysis, and subsequently to Cluster Analysis. Cluster analysis identified 4 homogeneous groups regarding annual rainfall distribution. The result showed relevance regarding physiographic aspects that characterize the rainfall dynamics in CRJ, highlighting areas favorable to the occurrence of natural disasters.

\section{Introduction}

Understand the spatial and temporal distribution of rainfall with the identification of Homogeneous Regions for Rainfall Distribution (HRRD) is fundamental mainly for cities that showed an increase in urbanization and changes in rainfall distribution, because rainfall is the most important triggering factor of natural hazards. Excess or scarcity of rainfall can be harmful due to the occurrence of droughts, floods, mass movements and even deaths. Floods are the most serious natural disasters in the world, which put more lives at risk and cause economic and social damage than any other natural phenomenon (Gigovic et al. 2017). A considerable increase in the risk of flooding in large cities is expected, mainly as a result of climate change, which could further aggravate the social impacts of disasters (Aznar-Crespo et al. 2021). Mass movements and landslides are natural hazards that threaten life (Mangeney, 2011).

Changes in the distribution of rainfall are already being observed in Rio de Janeiro (Machado et al. 2010; Pristo et al. 2018; Bunhak and Wanderley, 2020). However, the relationship between protected areas and natural disasters is scarce for the city of Rio de Janeiro (CRJ). The identification HRRD can serve as a support for mitigating the impacts caused by the rainfall. HRRD are regions that have statistical similarities in the distribution of rainfall over a long period of time (Hosking and Wallis, 1997; Terassi and Galvani, 2017).

The increase in urban population has become a challenge, since a lot of human activities are carried out in urban areas. This challenge has reached an alarming proportion in the last six decades, as the urban population has shown significant increase, which contributed for the urban population to exceed $50 \%$ of the world population (Alexander et al. 2016). The increase in urban population provides effects and changes in relation to the natural environment, in which large areas composed of native vegetation are 
replaced by urban buildings, which contributes to increasing air temperature, changing the rainfall regime and causing natural disasters (Gheno et al. 2012; Wanderley et al. 2019). In this context, urban forests have beneficial effects on cities by reducing air temperature, mitigating the effect of urban heat island, acoustic softening, filtering air polluting particles, increasing water infiltration in the soil, reducing landslides and above all increasing rainfall (Dacanal et al. 2010; Lima et al. 2010; France, 2012; Wanderley and Miguel, 2019).

For cities like Rio de Janeiro, where one of the world's largest urban forests is located, understanding the role of the forest in the characterization of the urban microclimate is fundamental, especially regarding the knowledge of spatial and temporal rainfall distribution. Rainfall is the fundamental meteorological element to define and characterize the climate of a region, being essential for the urban supply of large urban centers, such as CRJ and to define the most frequent natural disasters (Wanderley and Bunhak, 2016). Rainfall distribution in CRJ suffers significant variations due to its topography, as its development took place around three large massifs. CRJ massifs are continuously positioned, forming a triangle composed of the Tijuca massif (MTJ), in the central portion of the city, the Pedra Branca massif and the Gericinó massif.

MTJ is a geomorphological system located in the city of Rio de Janeiro, with rugged and varied relief (Dacanal et al. 2010). This massif consists of mountains and hills, with slopes facing the North at Jacarepaguá, the central portion of CRJ and the Atlantic Ocean, separating the Northern and Southern neighborhoods of the city. The influence of MTJ in the microclimate of CRJ was already ratified when MTJ initially contained a dense forest, which was strictly deforested for the purpose of supplying loggers, for charcoal production and later for coffee plantation. One of the consequences of this deforestation was one of the highest water deficits established in CRJ during the Empire period in Brazil.

Today, the major problem of rainfall distribution in MTJ and its surroundings is the increase in intense rainfall events, since this region has the highest rainfall totals and the highest occurrences of natural disasters in CRJ (D'orsi et al. 2016; Maia, 2012). These characteristics increase the number of natural disasters associated with rainfalls, and consequently the number of deaths. Disasters caused by rainfalls in CRJ show that destruction has been part of the city's daily life for centuries. Initial records have shown that back in 1575, Father José de Anchieta wrote a letter to another Jesuit with reports on the occurrence of heavy rains in the city. The occurrence of heavy rains of $1711,1756,1779,1803,1811$ should also be highlighted, which destroyed part of Morro do Castelo, leaving victims, 1833, 1862, 1864, 1906, 1911, 1928 and 1966 with 250 deaths and 50 thousand homeless (Marzban and Sandgathe, 2006).

However, the real influence of MTJ on the rainfall distribution in the city of Rio de Janeiro has not been quantified due to the lack of studies in this area of the city, in particular the HRRD in CRJ. There are a range of methods available to identify rainfall homogeneous regions. These methods can be broadly classified into four, namely, geographical convenience, subjective partitioning, objective partitioning and multivariate analysis (Hosking and Wallis, 1997). Multivariate analysis, in particular cluster analysis (CA) and principal component analysis (PCA), are prevalently used across various research studies to group 
meteorological stations with similar observations (Terassi and Galvani, 2017; Rasheed et al. 2019). For this characterization, the literature highlights the use of Cluster analysis, which identifies clusters (groups) whose members are similar to each other (Yussouf et al. 2004; Johnson and Wang, 2011; Hoffmann et al. 2019; Scott et al. 2019). Cluster analysis is a useful statistical tool to identify existing patterns in rainfall distribution, being able to classify groups into climatologically homogeneous regions. Thus, this study aims to identify homogeneous regions for rainfall distribution in the city of Rio de Janeiro associated to the risk of natural disasters.

\section{Material And Methods}

\section{Study Area}

The study analyzed the rainfall distribution in the MTJ region and its surroundings, located in the city of Rio de Janeiro. This region stands out in the city due to the large number of geological-geotechnical disasters (D'orsi et al. 2016). MTJ is a geomorphological complex in which the Três Rios, Pedra da Gávea, Serra da Carioca Mountains, and Tijuca National Park are located. In MTJ, Atlantic Forest fragments make up the Tijuca National Park (TNP), located in the city of Rio de Janeiro $\left(22^{\circ} 25^{\prime}\right.$ and $23^{\circ} 01^{\prime} \mathrm{S}$ and $43^{\circ} 12^{\prime}$ and $\left.43^{\circ} 19^{\prime} \mathrm{W}\right)$. The park has mountainous relief $(80$ to $1,021 \mathrm{~m})$ and tropical altitude climate. The vegetation is classified as Dense Ombrophilous Forest with stretches with varied successional stages and degraded portions covered by different heliophilous species (Coelho Netto, 2005).

\section{Database}

For analysis, monthly rainfall totals from 14 pluviometric stations spatially distributed in the study area (Fig. 1) between January 1997 and December 2018 were used. Rainfall data come from the "Alerta Rio" System (http://alertario.rio.rj.gov.br). Rainfall data were submitted to Cluster Analysis to identify HRRD in $\mathrm{CRJ}$ in order to identify regions at greater risk for the occurrence of natural disasters. Pluviometric stations selected for the study are located on MTJ and its surroundings, covering the windward region, close to the sea, in mountainous regions, in the leeward region and also in more continental lowland regions. Among stations used in the analysis, the Alta da Boa Vista station is the only one with information from April 2010. Although it has different interval from the others, the use of information collected by this station is essential, as it is located on MTJ, being the highest altitude station. The geographical information used in the analysis is shown in Table 1. 
Table 1

Geographical information of stations used in the study.

\begin{tabular}{|llll|}
\hline Stations & Latitude & Longitude & Level (m) \\
\hline Vidigal & $-22,99^{\circ}$ & $-43,23^{\circ}$ & 85 \\
\hline Rocinha & $-22,98^{\circ}$ & $-43,25^{\circ}$ & 160 \\
\hline Tijuca & $-22,93^{\circ}$ & $-43,22^{\circ}$ & 340 \\
\hline Sta. Tereza & $-22,93^{\circ}$ & $-43,19^{\circ}$ & 170 \\
\hline Copacabana & $-22,98^{\circ}$ & $-43,19^{\circ}$ & 90 \\
\hline Grajau & $-22,92^{\circ}$ & $-43,27^{\circ}$ & 80 \\
\hline Madureira & $-22,87^{\circ}$ & $-43,34^{\circ}$ & 45 \\
\hline Piedade & $-22,89^{\circ}$ & $-43,31^{\circ}$ & 50 \\
\hline Jacarepaguá & $-22,91^{\circ}$ & $-43,36^{\circ}$ & 73 \\
\hline Jard. Botânico & $-22,97^{\circ}$ & $-43,22^{\circ}$ & 0 \\
\hline Barra_Itanhagá & $-23,01^{\circ}$ & $-43,29^{\circ}$ & 7 \\
\hline Cidade de Deus & $-22,95^{\circ}$ & $-43,36^{\circ}$ & 15 \\
\hline Grande Meier & $-22,89^{\circ}$ & $-43,28^{\circ}$ & 25 \\
\hline Alto da Boa Vista & $-22,97^{\circ}$ & $-43,28^{\circ}$ & 355 \\
\hline
\end{tabular}

\section{Cluster Analysis}

In order to identify regions with rainfall distribution homogeneity, monthly data were submitted to an exploration and data description tool, called cluster analysis (Fig. 2). Cluster analysis is a Descriptive Statistics technique with the purpose of identifying homogeneous groups and / or subgroups, or clusters, in the distribution of the variable under study, that is, rainfall in relation to the influence of the Tijuca massif and its vegetation cover. To group pluviometric data based on similarity measure, data were allocated into a multivariate matrix $n \times p, X=[X i j], i=1, \ldots, n ; j=1, \ldots, p$, which contains rainfall values observed in each station, where $\mathrm{Xij}$ is the rainfall value $\mathrm{j}$ in station $\mathrm{i}$ (Yussouf et al. 2004). Cluster analysis was performed using the Ward method, where the distance between clusters is quantified by the squared Euclidean distance (ED) (Eq. 1). The distance between clusters is defined as the increase in the sum of squares of errors that would result from merging them into a single cluster (Ward, 1963). The Ward's method consists of a hierarchical grouping procedure, in which similarity is used to define clusters.

$$
d_{i j}=\left(\sum_{k=1}^{p}\left(x_{i k}-x_{j k}\right)^{2}\right)^{\frac{1}{2}}=\sqrt{\left(x_{i 1}-x_{j 1}\right)^{2}+\left(x_{i 2}-x_{j 2}\right)^{2}+\cdots\left(x_{i p}-x_{j p}\right)^{2}}
$$


where,

$\mathrm{x}_{\mathrm{ik}}$ - is the value of the $\mathrm{k}$ variable for i observation;

$\mathrm{x}_{\mathrm{jk}}-$ is the value of the $\mathrm{k}$ variable for $\mathrm{j}$ observation.

This method uses an attribute to group objects by similarity and dissimilarity measures. Dissimilarity was calculated for all pairs of stations, allowing comparison between them, by the dissimilarity measure presented between them, grouping them according to the lowest ED into equal groups Ward (1963). The ED is a numerical measure of dissimilarity of how different two data objects vary from 0 for objects are similar and $\infty$ for the objects are different.

\section{Results And Discussion}

\section{Homogeneous groups}

Cluster analysis identified 4 homogeneous groups regarding annual rainfall distribution associated to the risk of natural disasters, for stations located in MTJ and its surroundings (Fig. 3). Regionalization on the basis of the properties of hydro-meteorological data helps in identifying the regions reflecting the similar characteristics which could be useful in designing hydrological structures as well as planning and management of water resources of the region (Goyal et al., 2019). Clustering result showed relevance to the physiographic aspects that characterize the rainfall dynamics in CRJ. Local orography is a key modulator of the spatiotemporal connections and substantially enhances the probability of cooccurrence of extreme precipitation events even for distant locations (Mastrantonas et al. 2021). The dendrogram shows groups that were formed, where each group gathers rainfall stations that have the greatest similarity in the rainfall distribution behavior. The graphic representation of the dendrogram is characterized by the agglutination of stations that show similar rainfall distribution in CRJ, indicated by stations that make up each group. The dissimilarity obtained for clusters was small or close to zero, indicating that the groups and / or subgroups formed have similarities in the rainfall distribution behavior.

Proximity matrix of the Euclidean distance between the stations of each group can be seen in Table 2. The results found show that stations with shorter Euclidean distance show greater similarity, with dissimilarity being the degree of distance between the stations. 
Table 2

Proximity matrix of the Euclidean distance between stations.

\begin{tabular}{|c|c|c|c|c|c|c|c|c|c|c|c|c|c|c|}
\hline & V & $\mathbf{R}$ & $\mathrm{T}$ & $\mathrm{Sta}_{\mathrm{T}}$ & C & G & $M$ & $P$ & $\mathbf{J}$ & J B & B I & $C D$ & $A B V$ & G \\
\hline V & 0.0 & 1.5 & 1.0 & 1.1 & 0.7 & 1.3 & 1.5 & 1.4 & 1.4 & 0.7 & 0.9 & 1.3 & 2.2 & 1.4 \\
\hline $\mathrm{R}$ & & 0.0 & 2.1 & 1.9 & 2.1 & 2.6 & 2.7 & 2.6 & 2.6 & 1.2 & 1.0 & 2.5 & 2.6 & 2.6 \\
\hline$T$ & & & 0.0 & 0.6 & 0.7 & 0.8 & 1.3 & 1.2 & 1.2 & 1.1 & 1.5 & 1.1 & 3.0 & 1.1 \\
\hline $\begin{array}{l}\text { Sta } \\
T\end{array}$ & & & & 0.0 & 0.9 & 1.2 & 1.3 & 1.3 & 1.2 & 1.1 & 1.2 & 1.1 & 3.1 & 1.2 \\
\hline C & & & & & 0.0 & 0.9 & 1.1 & 1.0 & 1.0 & 1.1 & 1.4 & 0.8 & 2.7 & 1.0 \\
\hline G & & & & & & 0.0 & 0.9 & 0.8 & 0.9 & 1.6 & 1.8 & 0.7 & 2.8 & 0.7 \\
\hline M & & & & & & & 0.0 & 0.3 & 0.3 & 1.8 & 1.9 & 0.4 & 3.0 & 0.5 \\
\hline$P$ & & & & & & & & 0.0 & 0.4 & 1.7 & 1.8 & 0.4 & 2.9 & 0.3 \\
\hline $\mathrm{J}$ & & & & & & & & & 0.0 & 1.7 & 1.8 & 0.3 & 2.9 & 0.4 \\
\hline$J B$ & & & & & & & & & & 0.0 & 0.7 & 1.6 & 2.6 & 1.7 \\
\hline B I & & & & & & & & & & & 0.0 & 1.7 & 2.4 & 1.8 \\
\hline$C D$ & & & & & & & & & & & & 0.0 & 2.8 & 0.3 \\
\hline $\begin{array}{l}\mathrm{AB} B \\
\mathrm{~V}\end{array}$ & & & & & & & & & & & & & 0.0 & 2.9 \\
\hline GM & & & & & & & & & & & & & & 0.0 \\
\hline
\end{tabular}

wherein: V = Vidigal; R = Rocinha; $\mathrm{T}$ = Tijuca; Sta T = Santa Tereza; C = Copacabana; $\mathrm{G}$ = Grajaú; $\mathrm{M}$ = Madureira; $\mathrm{P}=$ Piedade; $\mathrm{J}=$ Jacaré; $\mathrm{J} \mathrm{B}=$ Jardim Botânico; $\mathrm{B} \mathrm{I}=$ Barra Itanhanga; $\mathrm{C} D=$ Cidade de Deus; $\mathrm{A}$ $\mathrm{B} V=$ Alto da Boa Vista and $\mathrm{G} M=$ Grande Meir.

Homogeneous rainfall distribution groups were characterized as follows: Group-I (light blue) composed of Vidigal, Rocinha, Jardim Botânico and Barra Itanhangá stations. Group-II (dark blue) composed of only one station, Alto da Boa Vista. Group-III (pink) represented by Tijuca, Santa Tereza, Copacabana and Grajaú stations. Group-IV (green), composed of Piedade, Grande Méier, Madureira, Cidade de Deus and Jacarepaguá stations. The results found show that stations with lower ED show greater similarity, and dissimilarity was the distancing degree between stations. Group 1 (light blue), from right to left on the dendrogram, is composed of Vidigal, Rocinha, Jardim Botânico and Barra Itanhangá stations. This result shows that the annual rainfall distribution behaved with greater similarity for these stations. Vidigal and Jardim Botânico stations were a subgroup due to the greater rainfall distribution similarity, which can be observed in Table 3. 
Table 3

Statistics of the monthly rainfall $(\mathrm{mm})$ of the stations the Groups.

\begin{tabular}{|c|c|c|c|c|c|c|c|c|c|}
\hline Group & Station & Min & Max & Sum & Mean & Variance & SD & Median & CV \\
\hline \multirow[t]{4}{*}{ । } & Vidigal & 57.9 & 151.0 & 1284.0 & 107.0 & 739.6 & 27.2 & 102.5 & 25.4 \\
\hline & Rocinha & 85.5 & 185.8 & 1686.4 & 140.5 & 1016.4 & 31.9 & 144.8 & 22.7 \\
\hline & Jard. Botânico & 66.4 & 161.5 & 1430.5 & 119.2 & 878.5 & 29.6 & 119.6 & 24.9 \\
\hline & Barra_Itanhaga & 66.2 & 177.3 & 1562.6 & 130.2 & 1258.3 & 35.5 & 128.4 & 27.2 \\
\hline ॥ & $\begin{array}{l}\text { Alto da Boa } \\
\text { Vista }\end{array}$ & 97.5 & 257.2 & 2078.6 & 173.2 & 2518.6 & 50.2 & 173.5 & 29.0 \\
\hline \multirow[t]{4}{*}{ III } & Tijuca & 53.7 & 191.6 & 1516.8 & 126.4 & 1982.2 & 44.5 & 119.0 & 35.2 \\
\hline & Sta Tereza & 48.4 & 165.6 & 1302.4 & 108.5 & 1393.9 & 37.3 & 104.2 & 34.4 \\
\hline & Copacabana & 41.4 & 143.0 & 1124.2 & 93.7 & 884.2 & 29.7 & 88.6 & 31.7 \\
\hline & Grajau & 38.4 & 178.0 & 1223.4 & 102.0 & 2137.9 & 46.2 & 96.2 & 45.4 \\
\hline \multirow[t]{5}{*}{ IV } & Madureira & 25.9 & 184.3 & 1061.5 & 88.5 & 2380.0 & 48.8 & 82.7 & 55.2 \\
\hline & Piedade & 30.8 & 179.8 & 1079.1 & 89.9 & 2135.9 & 46.2 & 85.3 & 51.4 \\
\hline & Jacarepaguá & 32.8 & 174.6 & 1082.8 & 90.2 & 1994.2 & 44.7 & 82.4 & 49.5 \\
\hline & Cidade_Deus & 38.8 & 156.7 & 1078.9 & 89.9 & 1309.4 & 36.2 & 85.8 & 40.2 \\
\hline & Grande_Meier & 27.4 & 194.3 & 1139.5 & 95.0 & 2984.8 & 54.6 & 88.4 & 57.5 \\
\hline
\end{tabular}

Min - minimum value, Max - maximum value, SD - standard deviation, CV- coeffient of variation.

The statistical analysis for stations that compose Group-I shows that Vidigal and Jardim Botânico stations present rainfall distribution similar to the other stations in the group. Thus, the lowest dissimilarity was observed for these two stations, with ED of 0.65 , being the lowest trunk height of GroupI. This proximity can also be observed by statistical parameters available in Table 3, with maximum, total, average, variance, standard deviation, median and the closest coefficient of variation. The greatest dissimilarity presented by Group-I was observed for Rocinha station, which is a result of the higher rainfall values measured in that station. This dissimilarity is a result of the higher altitude of the station and its position to the windward side of MTJ, which makes this station to present the highest total rainfalls in the group. In this station, ED was 1.53 for Vidigal station, 1.18 for Jardim Botânico and 1.02 for Barra Itanhangá stations. Mastrantonas et al. (2021) indicate the strong influence of orography on precipitation intensity. In the case of Barra Itanhangá station, ED proximity value was smaller for subgroup composed of Jardim Botânico (0.73) and Vidigal (0.87) than with Rocinha (1.02) stations. For this reason, Barra_Itanhangá station directly connects to this subgroup composed of Jardim Botânico and Vidigal stations. For the Rocinha station, the ED proximity value (1.02) was lower with Barra_Itanhangá station, resulting in similarity in the annual rainfall behavior. Cluster composed of 
Group-I stations is due to the proximity of stations to the coast, making stations to be positioned to the windward of the Tijuca massif slope, facing the ocean. This slope is influenced by ocean currents, the effect of sea breeze, showing forest cover around it (Fig. 4). These characteristics make neighborhoods that compose Group-I to have great potential for the occurrence of natural disasters.

The physical and geographic locations of Group-I stations, mainly Rocinha and Vidigal stations, commonly present natural disasters due to rainfalls. Considering that the Rocinha station presented, in this analysis, the second highest total rainfall in the city of Rio de Janeiro. An example is the case of mass movement and deaths that occurred in February 2019, in Rocinha. In Vidigal, in the same rainfall event, more than 40 houses were interdicted for presenting risk of landslides. As expected in the case of rainfall, those classes with high precipitation were more susceptible. Water is one of the most important causative factors in landslide occurrence. The increasing of some variables, such as pore water pressure, swelling of some clay minerals, and increasing the weight of unstable earth mass, which can cause a landslide, depend on the infiltrated water. In addition, water is a lubricant factor on a sliding surface that facilitates landslide occurrence (Varnes, 1984).

In addition to the orographic effect that occurs in CRJ, rainfall distribution is influenced by meteorological factors of macro and mesoscales such as the passage of frontal systems (FS), the South Atlantic Convergence Zone (SACZ) and occurrence of the Mesoscale Convective Systems (MCS), producing spatial irregularities in rainfall, with modulation of the Southern Annular Mode (SAM), Pacific Decadal Oscillation (PDO) and El Nino Southern Oscillation (ENSO) on seasonal scales.

Figure 5 shows the behavior of the monthly rainfall distribution in Group-l, where it is observed that the stations of Vidigal and Jardim Botânico have the smallest amplitude of the monthly rainfall distribution. This result confirms the smallest Euclidean distance found between stations.

Group-II (dark blue in the dendrogram) is composed only of one cluster, consisting of the Alto da Boa Vista station. This station has the highest dissimilarity values compared to all other stations, with values ranging from (2.24 for Vidigal) to (3.08 for Santa Tereza) and close to Group-I due to their common geographical and rainfall characteristics. Alto da Boa station was grouped in this way due to the fact that it presents attributes such as proximity to the ocean, to the windward side of the slope facing the ocean, great availability of forest cover and, above all, higher altitude among analyzed stations, which favors the effect of orography on rainfall formation. These characteristics make this station to present the highest minimum, maximum, average and total values of the city. The altitude of this station is a very important factor for the higher total rainfall values observed. This factor allows the formation of orographic rains on a local scale, which combined with macro and mesoscale systems, such as the entry of FS from the polar region, and with spring and summer convective systems, provide rainfalls in the region under analysis.

The systems that cause rainfalls in CRJ, in general moving from South to North and the presence of the topography force humid air to rise to the windward side of massifs. The rising air cools and condenses, forming clouds and rain, which produce maximum rains to the windward side of slopes, as observed in 
stations such as Rocinha and Tijuca. After reducing humidity, air comes down in slopes, being compressed and heated, thus inhibiting the formation of clouds and consequently reducing rainfall to the leeward side of massifs, explaining the lower totals in Group-IV. The Alto da Boa Vista station, located on the margin of TNP, is the one that best represents the importance of the presence of an urban forest in the city of Rio de Janeiro (Kong et al. 2015). The Tijuca forest is rich in biodiversity, located in a densely populated area in CRJ, which plays an important role in the city's microclimate, as observed in this analysis, providing the TNP station with average annual total rainfall greater than 2,000 mm $\mathrm{year}^{-1}$.

However, in the last decade, the urban forest of Tijuca has been suffering due to urban expansion, irregular occupation of forest areas and the cutting down of trees. This occupation makes society more vulnerable to natural disasters, which commonly occur in the study region, such as landslides and tree falls. The vulnerability is an important factor in determining overall vulnerability to flood hazards (Oulahen et al. 2015). Landslide is an important natural hazard, and therefore, recognition of both landslide-prone areas and landside susceptibility mapping is the interest of responsible organizations and researchers. The study of Opach et al. (2019) revealed clusters which allowed for a comprehensive interpretation of their community resilience through the unambiguous linking between well-delineated spatial areas and specific resilience signatures. The advantage of approach cluster is that both the magnitude and spatial structure of the precursors are utilized in generating the predictions of disasters (Totz et al. 2017).

One of these cases was the collapse of two buildings in Muzema, with twenty-two deaths due to heavy rainfalls in the region on April 2019. Of the 50 largest geological-geotechnical accidents in the city of Rio de Janeiro between 1966 and 2016, approximately 90\% of them were in the region analyzed in this research (Wanderley and Bunhak, 2016). According to Bradford et al. (2012), the public perception of risk must be in the centre of attention, because the authorities' lack of understanding the society is the reason for failure in the politics of flood risk management. Wachinger et al. (2012) review reveals that personal experience of a natural hazard and trust-or lack of trust in authorities and experts have the most substantial impact on risk perception. Cultural and individual factors such as media coverage, age, gender, education, income, social status, and others do not play such an important role but act as mediators or amplifiers of the main causal connections between experience, trust, perception, and preparedness to take protective actions. Knowledge of public risk perception is meant to assure an improvement in the effectiveness of flood risk management (Kellens et al. 2011).

In Fig. 6 it is noteworthy that between the months of April to June this was the only season among all to maintain high levels of rainfall and still obtain a slight increase in rainfall (173.5 $\mathrm{mm}$ to $181.7 \mathrm{~mm})$, while the other stations obtained a decrease in the same period.

Group-III (purple color in the dendrogram) was composed of Tijuca, Santa Tereza, Copacabana and Grajaú stations. This cluster is formed by two subgroups, one consisting of Tijuca and Santa Tereza stations and the other consisting of Copacabana and Grajaú stations. Subgroup composed of Tijuca and Santa Tereza stations should be highlighted. Rainfall distribution in these stations showed close 
minimum, total and average values. Thus, the dissimilarity presented by these stations was the lowest in the group, showing greater correlation than the others in rainfall distribution similarity, with ED value of (0.63). The rainfall distribution characteristic in Tijuca and Santa Tereza stations is due to the fact that these stations are located in regions of adequate forest cover in their surroundings and altitude higher than 150 meters to the leeward side of MTJ. Associated with these characteristics, stations are located in the vicinity of the Guanabara Bay, which favors greater influence of humidity not only from the ocean. The statistics of stations that compose Group-III prove this classification and seems to be analogous to that presented (Ward, 1963; Serra, 1970; Machao et al. 2010).

The Tijuca and Santa Tereza neighborhoods stand out with disasters associated with rainfalls due to the irregular occupation of hills and slums. There is a strong correlation between the slope degree and the landslide occurrence so that the weights are increased with a greater degree of the slope apart from the slope above fifty degrees (Varnes, 1984). Thus, landslide deaths are common, such as the three deaths at Morro do Borel, Tijuca, and the ten deaths and ten missing at Morro dos Prazeres, Santa Tereza, on April 2010. Benz and Blum (2019) showed the most intense cluster, happened in Rio de Janeiro, Brazil, as well as neighboring cities Niterói and São Gonçalo in 2010. In an area of approximately $2800 \mathrm{~km}^{2}, 111$ landslide events were recorded within only 3 day, predominantly on 6 April 2010. This is almost 4 times as many landslide events in a single day than the second most intense clusters (IDs 1 and 3 ) located in Washington and Oregon, US. The improvement of residents' knowledge about their environment and the residual risk seemed to be crucial to increase risk awareness, and the same was true for the strengthening of local support networks to foster preparedness (Scolobig et al. 2012).

Another very common problem observed in Tijuca is the frequent flooding, which led to the construction of three reservoirs with capacity of 119 million liters in the neighborhood. Heavy precipitation exerts strong societal and economic impacts, including flooding, and these precipitation events are projected to increase under anthropogenic warming. Zhang and Villarini (2017) find that the frequency of annual heavy precipitation at a global scale increases in both 1.5 and $2^{\circ} \mathrm{C}$ scenarios until around 2070 , after which the magnitudes of the trend become much weaker or even negative. Overall, the annual frequency of heavy precipitation across the globe is similar between 1.5 and $2^{\circ} \mathrm{C}$. Increase of this stagnation in temperature was observedin the city of Rio de Janeiro by Wanderley et al. (2019). Climate projections for the rest of the century show continued intensification of daily precipitation extremes. Increases in total and extreme precipitation in dry regions are linearly related to the model-specific global temperature change, so that the spread in projected global warming partly explains the spread in precipitation intensification in these regions by the late twenty-first century. This intensification has implications for the risk of flooding as the climate warms (Donat et al. 2016).

Stations of the other subgroup-III, Copacabana and Grajaú, presented the lowest minimum, total and average rainfall values, with values close to one another. However, distant variance, standard deviation and coefficient of variation values were observed. Thus, ED value among stations was 0.884 . Resulting from higher trunk height, it indicates lower similarity in rainfall distribution when compared to Tijuca and Santa Tereza stations. In the case of Copacabana and Grajaú stations, the rainfall distribution behavior is 
somehow different between stations. This is due to the fact that the Grajaú station is located in a region that still has a remaining forest cover, has forest reserve in balance with local constructions. In addition, its geographical position is closer to MTJ, the Grajaú station is thus influenced by the available humidity of the forest and the orographic factor in the formation of rains. The Copacabana station is the most distant from MTJ regarding stations that compose Group-III. Thus, the orographic effect on the rainfall distribution in that station is not observed. In addition, concrete buildings in the neighborhood are associated with one of the highest demographic density in the city of Rio de Janeiro. These characteristics make this station to present the lowest total rainfall of Group-III stations. However, flooding is often observed on the streets of the Copacabana neighborhood, as well as tree falls, with 5 events in February 2019. Floods represent about one-third of all natural disasters. Together with storms they comprise $77 \%$ of economic losses caused by extreme weather events in Europe (Lechowska, 2018). The city of São Paulo, home to 11 million people, suffers constantly the effects of flooding caused by extreme precipitation Haddad and Teixeira (2015) estimated that floods contributed to reduce city growth and residents' welfare, as well as hampering local competitiveness in both domestic and international markets. An intra-city total impact-damage ratio of 2.2 and an economy-wide total impactdamage ratio of 5.0 were found.

The behavior of these four seasons in the rainfall distribution, seen in Fig. 7, shows that for the Tijuca and Santa Tereza stations, the rainfall distribution on the annual scale was more similar, especially between the months of May and December, than in the other stations, composed by Grajaú and Copacabana.

Group-IV (green color in the dendrogram), was composed of Piedade, Grande Méier, Madureira, Cidade de Deus and Jacarepaguá stations. For these stations, it was verified that the subgroup composed of Madureira and Jacarepaguá stations had the lowest trunk height, with ED value of 0.26 . This indicates the lowest dissimilarity or the greatest similarity among all stations included in all groups formed. All Group-IV subgroups obtained the lowest dissimilarity values, close to zero, with ED values below 0.48 , which implies more HRRD for these locations, being therefore more similar than any other subgroup. This is because stations that compose Group-IV have similar characteristics in relation to their geographical positions in relation to MTJ. Some of the stations that compose this group are located to the leeward side of MTJ, thus receiving less or almost no influence from the relief due to the occurrence of orographic rains.

The topographic effect that causes orographic rains in Group-IV stations located to the windward side of the slope, has not been verified. Thus, rainfall distribution in these stations is due to macro and mesoscale synoptic systems, making maximum and minimum totals similar in these stations. This characteristic enables observing the lowest rainfall totals in stations under analysis. Group-IV stations are located in an area of great density, where there is practically no forest cover and greater distance from the Tijuca massif. These characteristics prevent the passage of humid winds from the Atlantic Ocean, causing low relative humidity and the appearance of heat islands. In addition, the location of stations away from the coast is a relevant attribute for the lower influence of the sea breeze. These characteristics 
confirm the lower annual rainfall totals observed in these stations. In these neighborhoods, the greatest problems caused by rainfalls are floods due to the overflow of rivers. The unplanned urbanization especially in developing countries and wide climate changes through global warming increase the risk of natural hazards. Landslide e Floods phenomenon are an important worldwide natural hazard.

The behavior of rainfall distributions for the stations that make up Group-IV behave very similarly and very close to each other throughout the year, being the most similar of all groups (Fig. 8).

The results of HRRD can be used by governments to identify critical areas of natural disasters, with the objective of developing actions that mitigate the impacts of the rainfall. These actions can be preventive measures with direct actions in neighborhoods such as: reforestation, infrastructure works, garbage collection, mapping of risk areas, rain forecasting and monitoring system, implementation of an operations center, audible warning sirens, weather radars. These actions can make CRJ more resilient, to heavy rainfall and natural disasters such as floods and landslides, mainly due to large daily rainfall totals.

Figure 9 shows the highest total rainfall values at Alto da Boa Vista stations during January and Rocinha in April (578.4 mm and $571 \mathrm{~mm}$ ). Both stations belonging to Group I and Group II. The lowest pluiviometric totals were found in Madureira belonging to Group IV, during the months of August 2015 and July 2016 , totaling only $0.6 \mathrm{~mm}$.

The ten largest daily rains in CRJ show that all stations in Group I and Group II have maximum daily rainfall greater than $300 \mathrm{~mm}$ day $^{-1}$. The storm that occurred in the CRJ on April 8 and 9 was the day with the highest rainfall in 24 hours since Alert Rio began its measurement in 1997 (ALERTA RIO, 2021). Ten people died due to the rains at the CJR on April 8 and 9. The stations of Rocinha, Alto da Boa Vista, Barrinha, Jardim Botânico, Copacabana, Vidigal, Rio Centro and Cidade de Deus recorded the highest rainfall in an interval of 24 hours. At the Sumaré station $360.2 \mathrm{~mm}$ were measured on 04/04/2010. However, the station was closed in May 2010. Sumaré station is located next to Alto da Boa Vista station. At Tijuca station, $286 \mathrm{~mm}$ were measured on 04/26/2011.Annual maximum daily precipitation data represent one of the most important and readily available measures of extreme rainfall and are used frequently as inputs to assessments of flood risk (Westra et al. 2013). The warm/ wet extremes appear to increase in tropical and high-latitude regions like Africa, the eastern part of South America, the Middle East, East Asia (Wu et al. 2012). Studies have shown that extreme temperature and precipitation events increased in the second half of the 20th century (Donat et al. 2016; Zhou et al. 2016). the study of Raymond et al. (2020) found that there have been increasing occurrences of extremely humid and hot weather that had been rare or unprecedented in the past in Asia, Africa, Australia, South America, and North America. Climate projections for the rest of the century show continued intensification of daily precipitation extremes (Donat et al. 2016).

To Brazil precipitation extremes show heterogeneous signals for most of the country. In Northeast Brazil, there are changes towards a drier climate, especially in summer and autumn. In the Southern region, the 
climate is becoming wetter, with a reduction in consecutive dry days, especially in spring. For the other regions, there is no strong clear change sign, but both positive and negative precipitation extreme trends, without statistical significance, mostly in Southeast Region where is it located CRJ (Regoto et al. 2021).

\section{Conclusions}

In this study, four homogeneous groups were identified due to rainfall distribution in the city of Rio de Janeiro regarding the risk of natural disasters. It was verified that the orography of the Tijuca massif is a determining factor for the grouping of stations and in the homogeneity of rainfalls in the city of Rio de Janeiro, with the highest rainfall totals being observed in higher altitude stations.

The grouping of stations into clusters was also due to the vegetal coverage rate and the proximity of stations to the Atlantic Ocean and Guanabara Bay. Stations located to the windward side of the massif, far from water bodies, have the lowest rainfall totals in the city of Rio de Janeiro.

Neighborhoods that compose Group-I and Group-II, and some that compose Group-III, are the most vulnerable to natural disasters due to greater rainfall and irregular occupation of hills and slopes.

\section{Declarations}

Acknowledgments We authors would like to thank the "Alerta Rio" System (http://alertario.rio.rj.gov.br) for the data worked during the development of this paper. The authors would also like to thank the Federal Rural University of Rio de Janeiro, for all the infrastructure for the development of this work.

Funding This study did not receive specifc funds.

Confict of interest The authors declare that they have no confict of interest.

Consent to participate The authors declare that this research would be used only for scientifc research and would not passed on to third parties.

Consent for publication The authors authorize the publication of this manuscript

\section{References}

1. ALERTA RIO - Sistema Alerta Rio da Prefeitura do Rio de Janeiro. Accessed in: 09 January 2020. Available from: http://alertario.rio.rj.gov.br/

2. Alexander PJ, Fealy R, Mills GM (2016) Simulating the impact of urban development pathways on the local climate: A scenario-based analysis in the greater Dublin region, Ireland. Landscape Urban Planning 152:72-89. https://doi.org/10.1016/j.landurbplan.2016.02.006

3. Aznar-Crespo P, Aledo A, Melgarejo-Moreno J, Vallejos-Romero A (2021) Adapting Social Impact Assessment to Flood Risk Management. Sustainability 13(6):3410. 
https://doi.org/10.3390/su13063410

4. Benz SA, Blum P (2019) Global detection of rainfall-triggered landslide clusters. Natural Hazards Earth System Sciences 19:1433-1444. https://doi.org/10.5194/nhess-19-1433-2019

5. Bradford RA, O’Sullivan JJ, Van Der Craats IM, Krywkow J, Rotko P, Aaltonen J, Bonaiuto M, De Dominici S, Waylen K, Schelfaut K (2012) Risk perception-issues for flood management in Europe. Natural Hazards Earth System Sciences 12:2299-2309. https://doi.org/10.5194/nhess-12-22992012

6. Bunhak AC, Wanderley HS (2020) Change in the number of rainfall days of city Visconde de Mauá, Rio de Janeiro. Journal of Biotechnology Biodiversity 8:297-303.

https://doi.org/10.20873/jbb.uft.cemaf.v8n4.bunhak

7. Coelho Netto A (2005) A interface florestal-urbana e os desastres naturais relacionados à água no maciço da tijuca: desafios ao planejamento urbano numa perspectiva sócio-ambiental. Revista do Departamento de Geografia 16:46-60. https://doi.org/10.7154/RDG.2005.0016.0005

8. D’orsi RN, Paes NM, Magalhães MA, Junior LRS, Valente LRS (2016) Os 50 maiores acidentes geológico-geotécnicos na cidade do Rio de Janeiro entre 1966 e 2016 . Fundação Instituto de Geotécnica do Município do Rio de Janeiro, Rio de Janeiro

9. Dacanal C, Labaki C, Silva TML (2010) Vamos passear na floresta! O conforto térmico em fragmentos florestais urbanos. Ambiente Construído 10:115-132. https://doi.org/10.1590/S167886212010000200008

10. Donat MG, Lowry AL, Alexander LV, O'Gorman PA, Maher N (2016) More extreme precipitation in the world's dry and wet regions. Nature Climate Change 6:508-513.

https://doi.org/10.1038/nclimate2941

11. France MS (2012) Microclimas e suas relações com o uso do solo no entorno de escolas públicas na cidade de Cuiabá/MT. Revista Educação Cultura e Sociedade 2:148-161

12. Gheno EL, França MS, Maitelli SF (2012) Variações microclimáticas na área urbana de Sinop no final da estação chuvosa. Revista Educação Cultura e Sociedade 2:139-153

13. Gigovic L, Pamucar D, Bajic Z, Drobnjak S (2017) Application of GIS-Interval Rough AHP Methodology for Flood Hazard Mapping in Urban Areas. Water 9(6):360. https://doi.org/10.3390/w9060360

14. Goyal MK, Shivam G, Sarma AK (2019) Spatial homogeneity of extreme precipitation indices using fuzzy clustering over northeast India. Natural Hazards, 98, 559-574.

https://doi.org/10.1007/s11069-019-03715-z.Haddad, E. A., Teixeira, E., (2015). Economic impacts of natural disasters in megacities: The case of floods in São Paulo, Brazil. Habitat International, 45, 106-113. https://doi.org/10.1016/j.habitatint.2014.06.023

15. Hoffmann F, Yamaguchi T, Feingold G (2019) Inhomogeneous Mixing in Lagrangian Cloud Models: Effects on the Production of Precipitation Embryos. J Atmos Sci 76:133-133. https://doi.org/10.1175/JAS-D-18-0087.1 
16. Hosking J, Wallis J (1997) Regional Frequency Analysis: An Approach Based on L-Moments. Cambridge University Press, Cambridge

17. Johnson A, Wang X (2011) Hierarchical Cluster Analysis of a Convection-Allowing Ensemble during the Hazardous Weather Testbed 2009 Spring Experiment. Part I: Development of the Object-Oriented Cluster Analysis Method for Precipitation Fields. Mon Weather Rev 139:3673-3693. https://doi.org/10.1175/MWR-D-11-00015.1

18. Kellens W, Zaalberg R, Neutens T, Vanneuville W, De Maeyer P (2011) An analysis of the public perception of flood risk on the Belgian coast. Risk Analysis, 31, 1055-1068.

https://doi.org/10.1111/j.1539-6924.2010.01571.x.Kong, F., Yin, H., James, P. (2014). Effects of spatial pattern of greenspace on urban cooling in a large metropolitan area of eastern China. Landscape and Urban Planning, 128, 35-47. https://doi.org/10.1016/j.landurbplan.2014.04.018

19. Lechowska $E$ (2018) What determines flood risk perception? A review of factors of flood risk perception and relations between its basic elements. Nat Hazards 94:1341-1366. https://doi.org/10.1007/s11069-018-3480-z

20. Lima KC, Satyamurty P, Fernández JPR (2010) Large-scale atmospheric conditions associated with heavy rainfall episodes in Southeast Brazil. Theoret Appl Climatol 101:121-135. https://doi.org/10.1007/s00704-009-0207-9

21. Machado RL, Ceddia MB, Carvalho DF, Cruz ES, Francelino MR (2010) Spatial variability of maximum annual daily rain under different return periods at the Rio de Janeiro state, Brazil. Bragantia 69:7784. https://doi.org/10.1590/S0006-87052010000500009

22. Maia ACN (2012) Imagens de uma cidade submersa: o Rio de Janeiro e suas enchentes na memória de escritores e fotógrafos. Revista Escritos 6:247-274

23. Mangeney A (2011) Landslide boost from entrainment. Nat Geosci 4:77-78. https://doi.org/10.1038/ngeo1077

24. Marzban C, Sandgathe S (2006) Cluster Analysis for Verification of Precipitation Fields. Weather Forecast 21:824-838. https://doi.org/10.1175/WAF948.1

25. Mastrantonas N, Herrera-Lormendez P, Magnusson L, Pappenberger F, Matschullat J (2021) Extreme precipitation events in the Mediterranean: Spatiotemporal characteristics and connection to largescale atmospheric flow patterns. Int J Climatol 41:2710-2728. https://doi.org/10.1002/joc.6985

26. Oulahen G, Shrubsole D, McBean G (2015) Determinants of residential vulnerability to flood hazards in Metro Vancouver, Canada. Nat Hazards 78:939-956. https://doi.org/10.1007/s11069-015-1751-5

27. Opach T, Scherzer S, Lujala P, Rød JK (2020) Seeking commonalities of community resilience to natural hazards: A cluster analysis approach. Norsk Geografisk Tidsskrift - Norwegian Journal of Geography 74:181-199. https://doi.org/10.1080/00291951.2020.1753236

28. Pristo MVJ, Dereczynski CP, Souza PR, Meneses WF (2018) Climatologia de Chuvas Intensas no Município do Rio de Janeiro. Revista Brasileira de Meteorologia 33:615-630. http://dx.doi.org/10.1590/0102-7786334005 
29. Rasheed A, Egodawatta P, Goonetilleke A, McGree J (2019) A Novel Approach for Delineation of Homogeneous Rainfall Regions for Water Sensitive Urban Design-A Case Study in Southeast Queensland. Water 11(3):570. https://doi.org/10.3390/w11030570

30. Raymond C, Matthews T, Horton RM (2020) The emergence of heat and humidity too severe for human tolerance. Science Advances 6:eaaw1838. https://doi.org/10.1126/sciadv.aaw1838

31. Regoto P, Dereczynski C, Chou SC, Bazzanela (2021) Observed changes in air temperature and precipitation extremes over Brazil. International journal of climatology, 25. https://doi.org/10.1002/joc.7119

32. Scolobig A, De Marchi B, Borga M (2012) The missing link between flood risk awareness and preparedness: findings from case studies in an Alpine Region. Natural Hazards, 63, 499-520. https://doi.org/10.1007/s11069-012-0161-1v.Scott, R. C., Nicolas, J. P., Bromwich, D. H., Norris, J. R., Lubin, D. (2019). Meteorological Drivers and Large-Scale Climate Forcing of West Antarctic Surface Melt. Journal of Climate, 32, 665-684. https://doi.org/10.1175/JCLI-D-18-0233.1

33. Serra AB (1970) Clima da Guanabara. Boletim Geográfico, 29. Fundação Instituto Brasileiro de Geografia e Estatística, pp 80-111

34. Terassi PMB, Galvani E (2017) Identification of Homogeneous Rainfall Regions inthe Eastern Watersheds of the State of Paraná, Brazil. Clima, 5 (3), 53; https://doi.org/10.3390/cli5030053

35. Totz S, Tziperman E, Coumou D, Pfeiffer K, Cohen J (2017) Winter Precipitation Forecast in the European and Mediterranean Regions Using Cluster Analysis. Geophys Res Lett 44:418-426. https://doi.org/10.1002/2017GL075674

36. Varnes DJ (1984) Landslide hazard zonation: a review of principles and practice. UNESCO, Paris

37. Wachinger G, Renn O, Begg C, Kuhlicke C (2013) The risk perception paradox - implications for governance and communication of natural hazards. Risk Anal 33:1049-1065. https://doi.org/10.1111/j.1539-6924.2012.01942.x

38. Wanderley $H$, Bunhak A (2016) Alteration in precipitation and number of days without rain in the southern region of Rio de Janeiro state). Revista Brasileira de Geografia Física 9:2341-2353. https://doi.org/10.5935/1984-2295.20160167

39. Wanderley HS, Fernandes RC, Carvalho AL (2019) Thermal change in the city of Rio de Janeiro and the deviation caused during an intense El Niño event. Revista Brasileira de Geografia Física 12:2364-2375. https://doi.org/10.26848/rbgf.v12.4.p1291-1301

40. Wanderley HS, Miguel VC (2019) Mudança dos elementos meteorológicos em função da degradação da floresta urbana. Ciência Florestal 29:834-843. https://doi.org/10.5902/1980509832090

41. Ward JH (1963) Hierarchical grouping to minimize an objective function. Journal of the American Statistical Association. J Am Stat Assoc 58:236-244. https://doi.org/10.2307/2282967

42. Westra S, Alexandre LV, Zwiers FW (2013) Global Increasing Trends in Annual Maximum Daily Precipitation. J Clim 26:3904-3918. https://doi.org/10.1175/JCLI-D-12-00502.1

43. Wu, Y., Miao, C., Sun, Y., Agha Kouchak, A., Shen, C., Fan, X. (2021). Global observations and CMIP6 simulations of compound extremes of monthly temperature and precipitation. GeoHealth, 5, 
e2021GH000390. https://doi.org/10.1029/2021GH000390.Yussouf, N., Stensrud, D. J., Lakshmivarahan, S. (2004). Cluster Analysis of Multimodel Ensemble Data over New England. Monthly Weather Review, 132, 2452-2462. https://doi.org/10.1175/15200493(2004)132<2452:CAOMED>2.0.C0;2.

44. Zhang W, Villarini G, Heavy (2017) Precipitation is highly sensitive to the magnitude of future warming. Clim Change 145:249-257. https://doi.org/10.1007/s10584-017-2079-9

45. Zhou B, Xu Y, Wu J, Dong S, Shi Y (2016) Changes in temperature and precipitation extreme indices over China: Analysis of a high-resolution grid data set. Int J Climatol 36:1051-1066. https://doi.org/10.1002/joc.4400

\section{Figures}

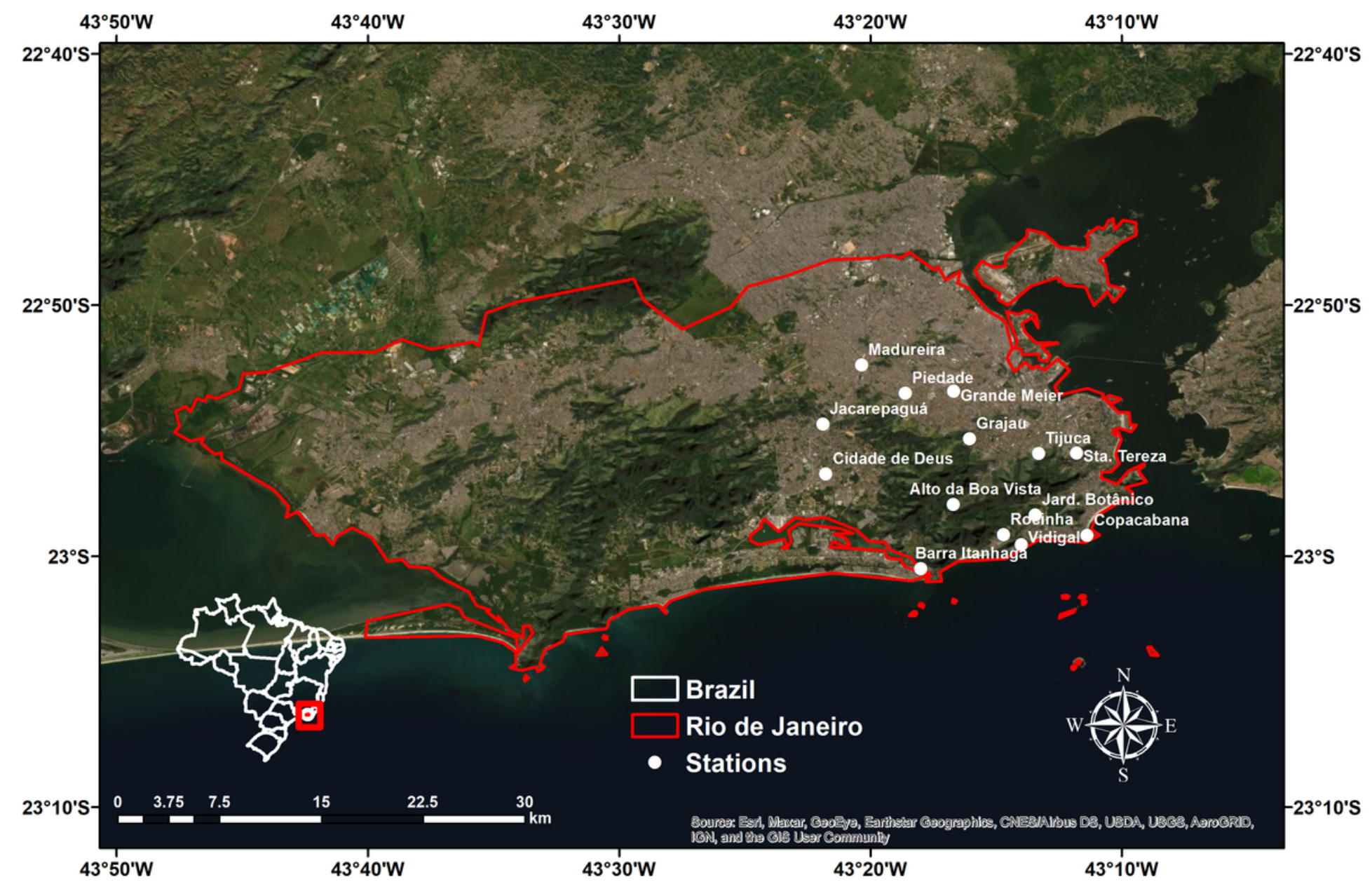

\section{Figure 1}

Geographical locations of the rainfall stations in the city of Rio de Janeiro. Note: The designations employed and the presentation of the material on this map do not imply the expression of any opinion whatsoever on the part of Research Square concerning the legal status of any country, territory, city or 
area or of its authorities, or concerning the delimitation of its frontiers or boundaries. This map has been provided by the authors.

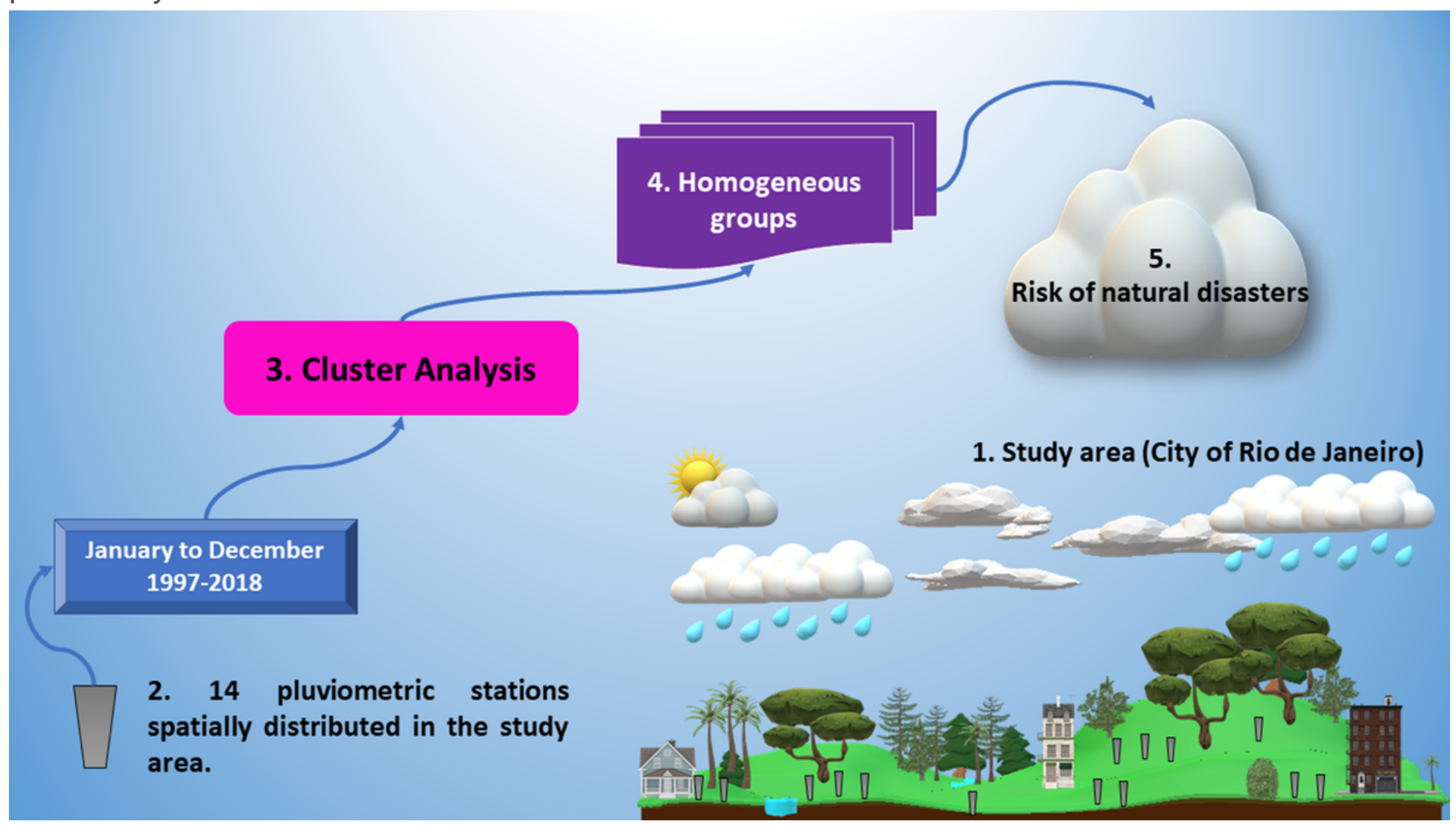

Figure 2

Cluster analysis and identification of homogeneous groups for 14 pluviometric stations in the city of Rio de Janeiro. 


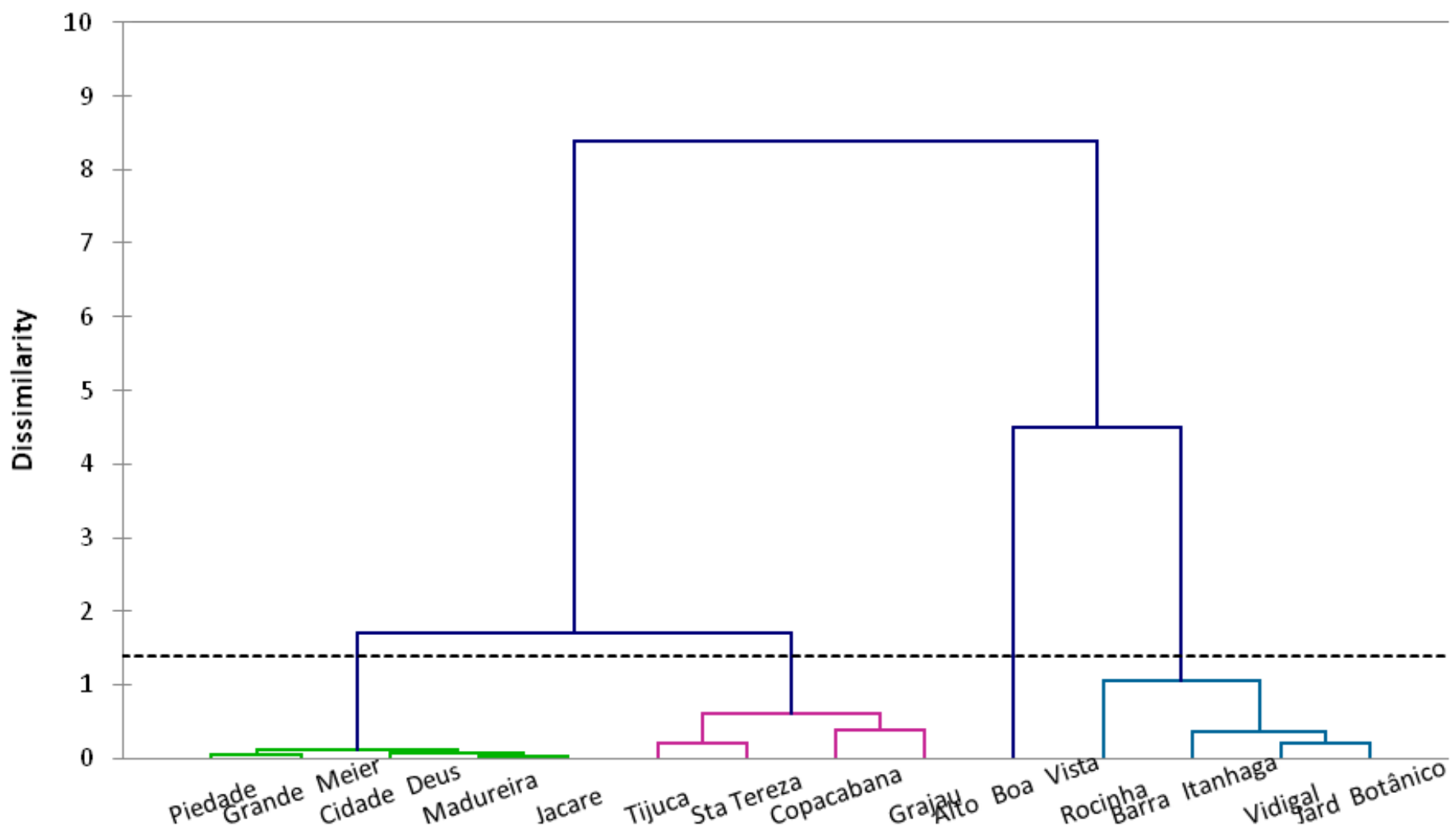

Figure 3

Dendrogram with the division of homogeneous groups. 


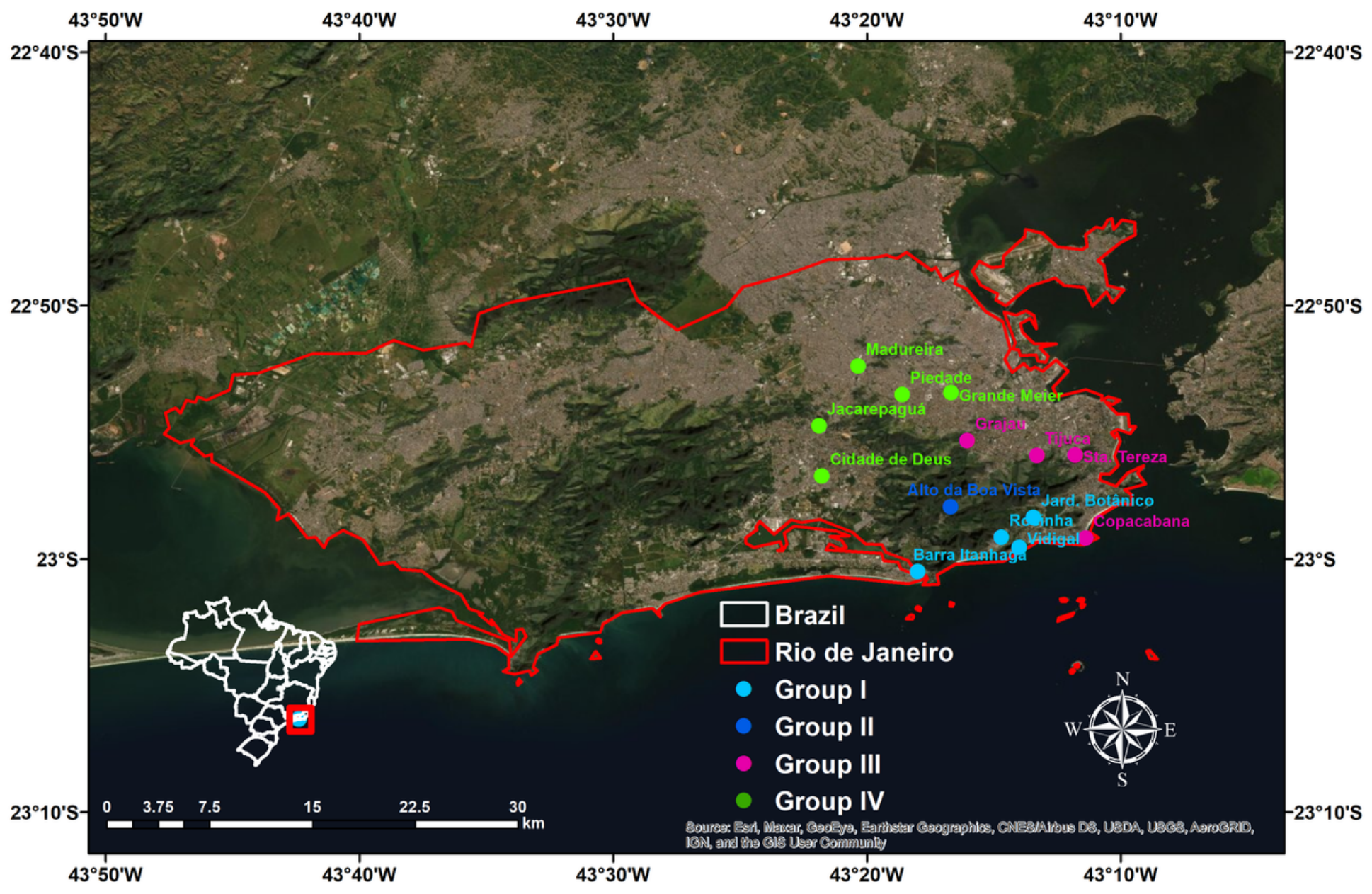

\section{Figure 4}

Homogeneous precipitation groups. Note: The designations employed and the presentation of the material on this map do not imply the expression of any opinion whatsoever on the part of Research Square concerning the legal status of any country, territory, city or area or of its authorities, or concerning the delimitation of its frontiers or boundaries. This map has been provided by the authors. 


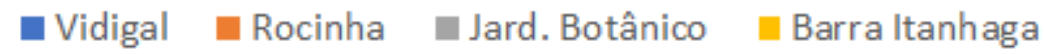

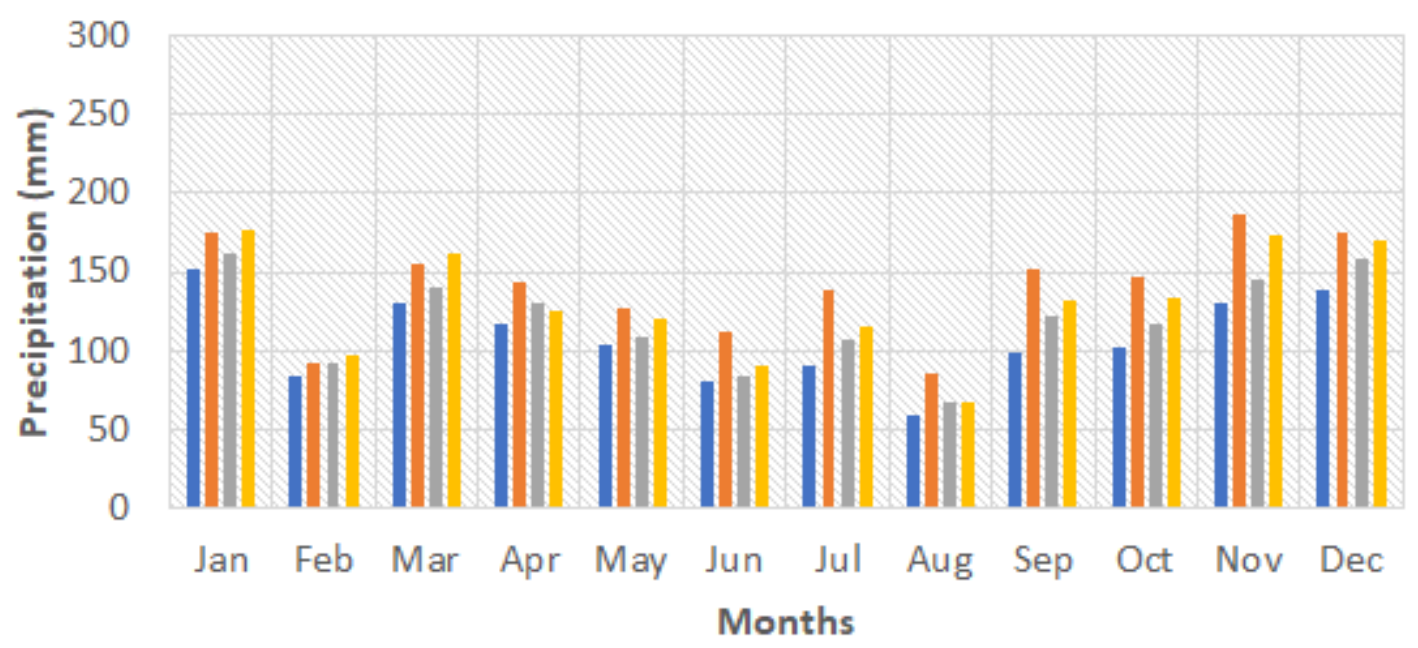

Figure 5

Monthly average of the precipitation of the stations of Group-I.

alto Boa Vista

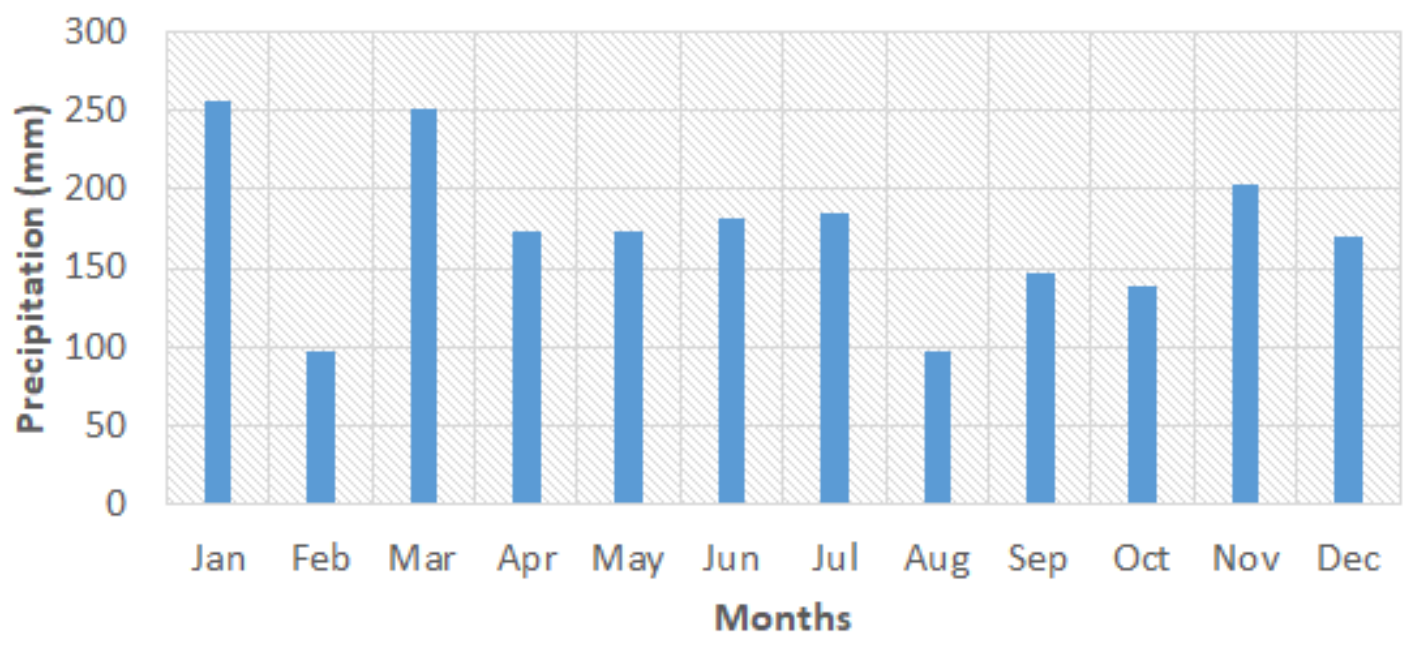

Figure 6

Monthly average rainfall for the Group-Il season. 


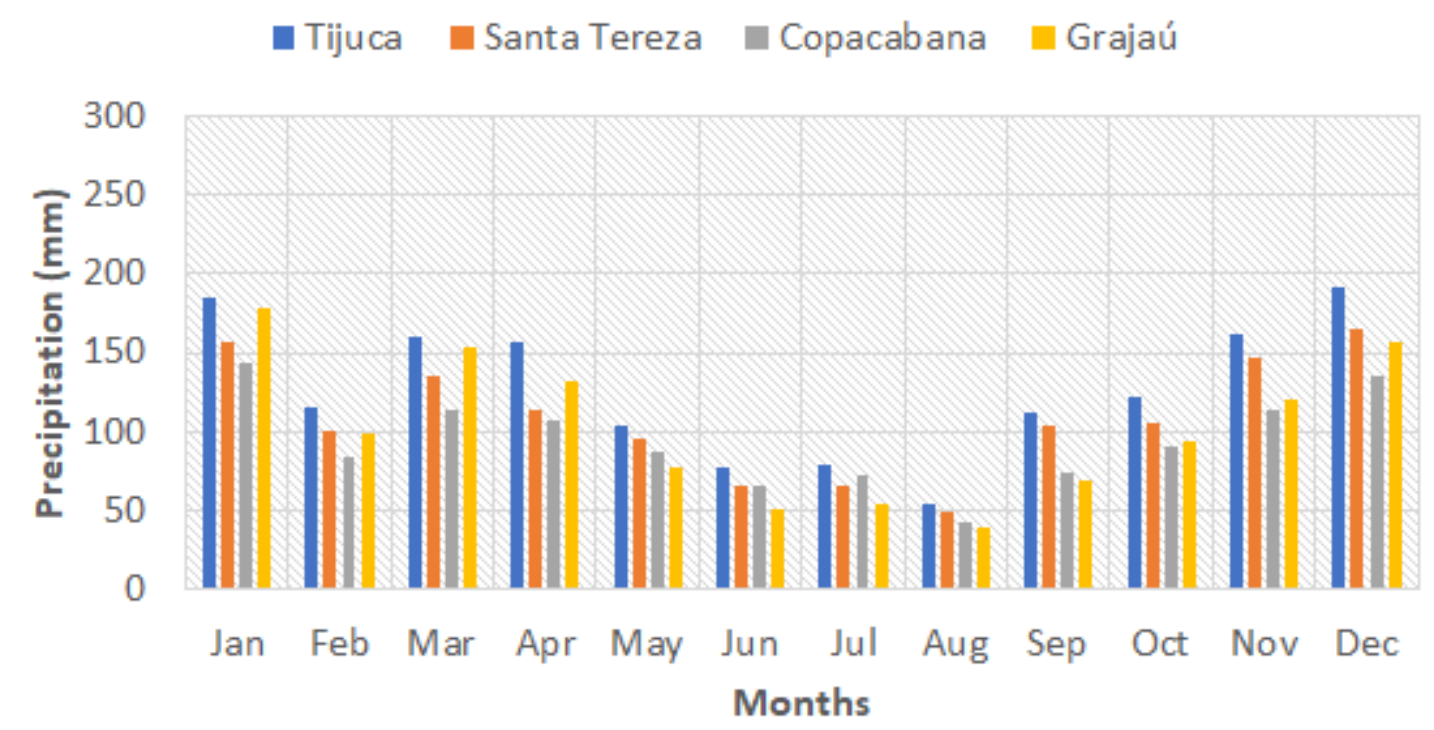

Figure 7

Monthly average of precipitation presented by Group-III.

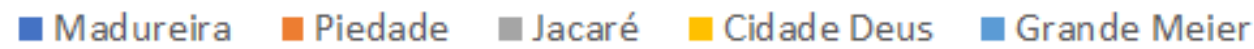

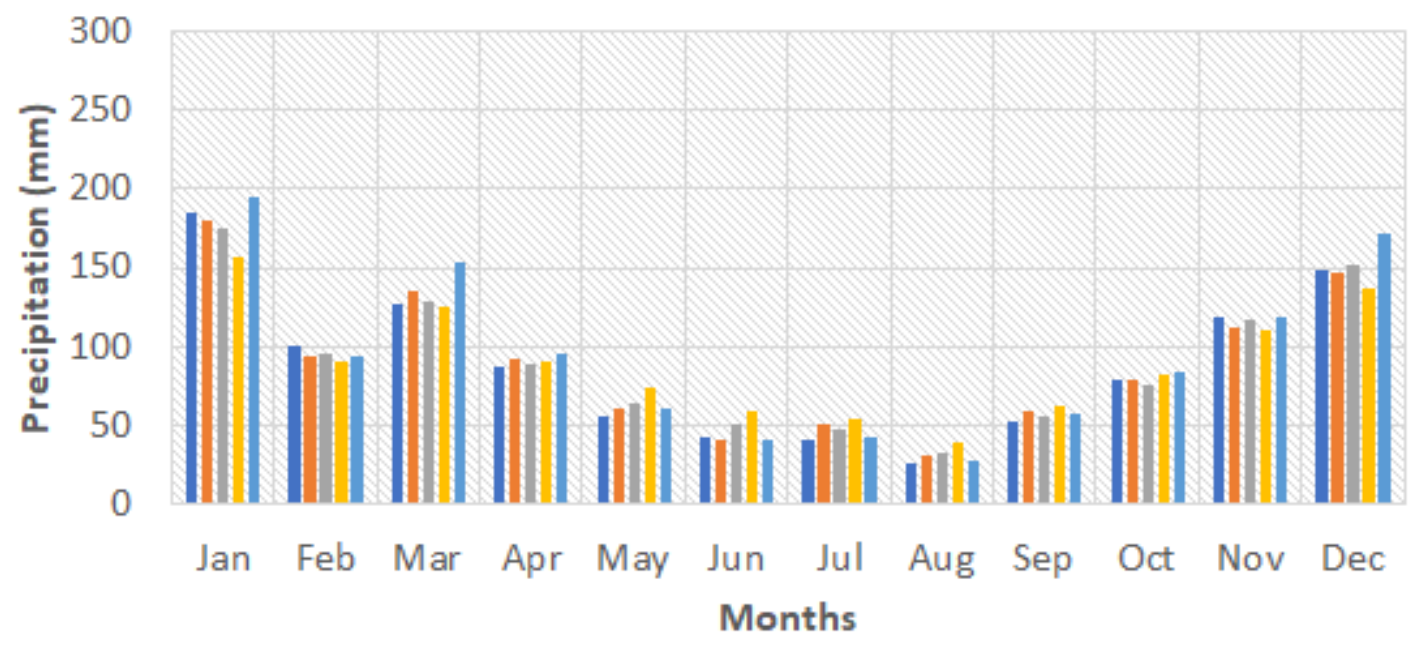

Figure 8

Monthly average of precipitation presented by Group-IV. 


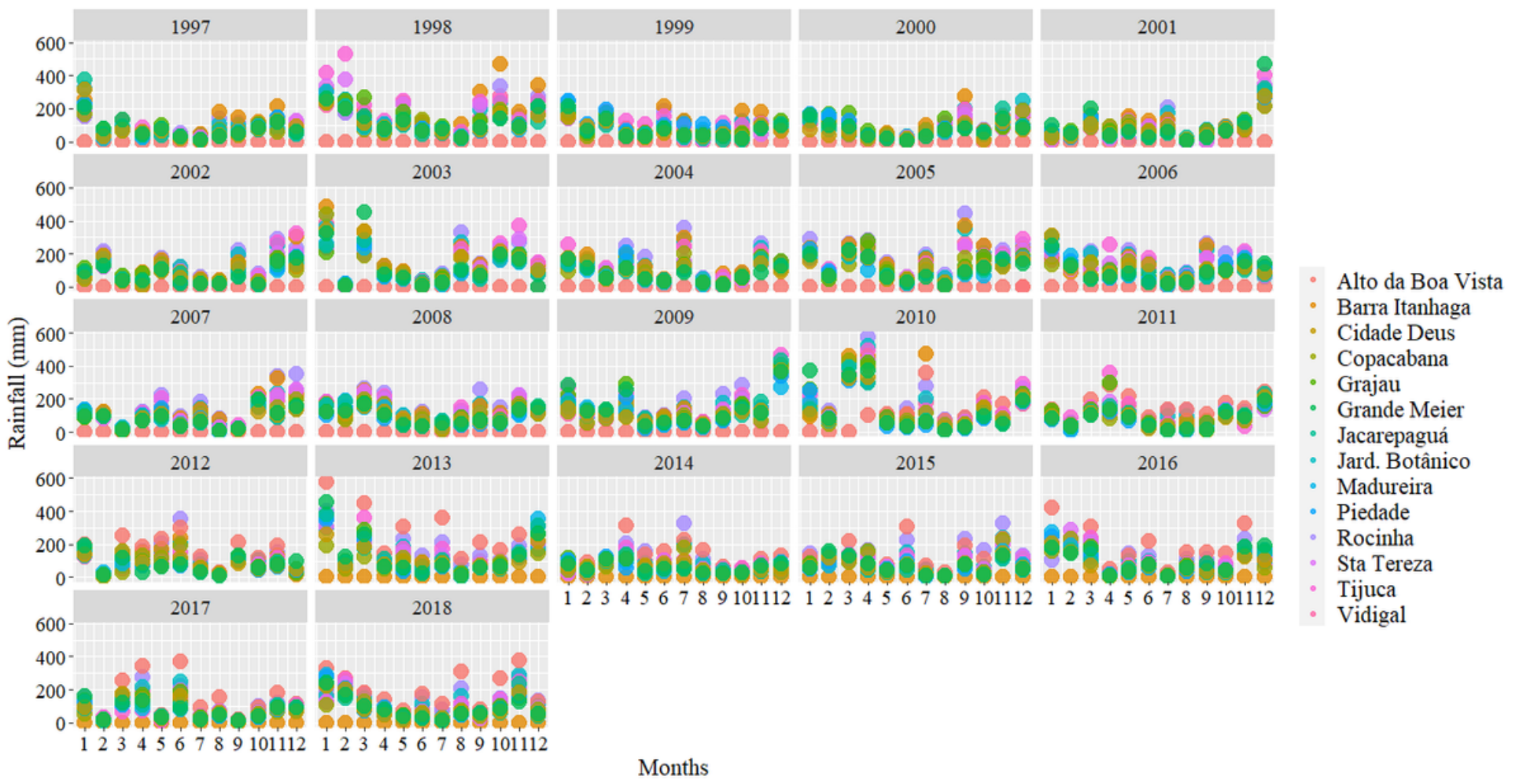

Figure 9

Total monthly precipitation values for the weather stations in the city of Rio de Janeiro. 